\title{
Difficult decisions in times of constraint: Criteria based Resource Allocation in the Vancouver Coastal Health Authority
}

\author{
Craig Mitton ${ }^{1,2}$, Francois Dionne ${ }^{1,2}$, Rizwan Damji ${ }^{3}$, Duncan Campbell ${ }^{3}$ and Stirling Bryan ${ }^{1,2}$
}

\begin{abstract}
Objectives: The aim of the project was to develop a plan to address a forecasted deficit of approximately $\$ 4.65$ million for fiscal year 2010/11 in the Vancouver Communities division of the Vancouver Coastal Health Authority. For disinvestment opportunities identified beyond the forecasted deficit, a commitment was made to consider options for resource re-allocation within the Vancouver Communities division.

Methods: A standard approach to program budgeting and marginal analysis (PBMA) was taken with a priority setting working committee and a broader advisory panel. An experienced, non-vested internal project manager worked closely with the two-member external research team throughout the process. Face to face evaluation interviews were held with 10 decision makers immediately following the process.

Results: The recommendations of the working committee included the implementation of 44 disinvestment initiatives with an annualized value of CAD $\$ 4.9$ million, as well as consideration of possible investments if the realized savings match expectations. Overall, decision makers viewed the process favorably and the primary aim of addressing the deficit gap was met.

Discussion: A key challenge was the tight timeline which likely lead to less evidence informed decision making then one would hope for. Despite this, decision makers felt that better decisions were made then had the process not been in place. In the end, this project adds value in finding that PBMA can be used to cover a deficit and minimize opportunity cost through systematic application of criteria whilst ensuring process fairness through focusing on communication, transparency and decision maker engagement.
\end{abstract}

Keywords: priority setting, health care decision-making, disinvestment

\section{Background}

As part of the fallout from the 2008 global economic crisis there has been extreme pressure on public sector spending. Across most countries, including Canada, deficits have increased dramatically leaving government departments having to either identify operational efficiencies or cut services. In the rare instance where additional investment in a particular area is made, such expansion is only achievable at a very real and potentially crippling effect on other departments, as was recently the case in the Province of Alberta.

\footnotetext{
* Correspondence: craig.mitton@ubc.ca

${ }^{1}$ Centre for Clinical Epidemiology and Evaluation, Vancouver Coastal Health Research Institute, Vancouver, Canada

Full list of author information is available at the end of the article
}

Interestingly, recent polls in Canada suggest that members of the public favor a reduction in public sector services over increases to income tax or sales tax. However, when specific cuts are identified, the cries of injustice are quick to make front-page news.

The fact is there are only so many resources to go around. This has been well documented in the health sector for many years and thus clearly pre-dates the most recent recession. What perhaps has made the recent move toward cuts in health care less palatable is that, in Canada as elsewhere, this has followed on the wake of over a decade of year on year real increases in expenditure. Nonetheless, the notion of decommissioning of health services has started to gain some traction. For example, the UK's National Institute of Health and
Ciomed Central 
Clinical Excellence (NICE) recently indicated a focus on appraisal of not only technologies for investment but also areas for disinvestment [1]. Several recent papers have also addressed the issue of disinvestment, discussing potential avenues for such action [2].

The Program Budgeting and Marginal Analysis (PBMA) framework was implemented in the Vancouver Coastal Health Authority (VCH) on a pilot basis from January to March 2010. VCH is one of six health authorities in British Columbia and with an annual operating budget of approximately CAD $\$ 3 B$ provides services across the full continuum of care for about one million residents in Metro Vancouver. The specific focus of the exercise was within Vancouver Community Services, a major division within the health authority providing a mix of direct and contracted-out non-acute services. The primary aim of the project was to develop a plan to address the forecasted deficit of approximately $\$ 4.65$ million for fiscal year 2010/ 11 on a $\$ 280 \mathrm{M}$ budget. For disinvestment opportunities identified beyond the forecasted deficit, a commitment was made to consider options for resource re-allocation within the Vancouver Communities division.

This paper outlines the approach taken with respect to PBMA implementation and provides results that followed in terms of real decisions by the Senior Executive Team of the health authority. Lessons learned and areas for improvement are also described based on findings from a formal post-exercise evaluation with key decision makers. One challenge of PBMA identified in the past has been difficulty in generating and acting upon disinvestment options [3]. This action research project provides an example of success in terms of achieving disinvestments and thus factors for this are explored. In this, we consider the question as to whether PBMA can only have a large impact on disinvestment if there is external fiscal pressure. This paper should be acutely relevant to health care decision makers facing potential cuts of their own, as well as health services researchers likely to be called upon to support such activity.

\section{Methods}

A standard approach to PBMA was taken [4], with a priority setting working committee comprised of all
Directors and Clinical Leads from Vancouver Communities ( $\mathrm{n}=15)$, as well as a broader Advisory Panel that included a mix of Vancouver Communities personnel and Senior Executive members $(n=8)$. The Advisory Panel reported to the Senior Executive Team, which has final decision-making authority within the organization subject to Board approval as necessary. An experienced, non-vested internal project manager worked closely with the two-member external research team throughout the process. The research team acted as participant observers within an action research frame. The functions of each group are outlined in Table 1 . The steps followed for PBMA implementation are depicted in Figure 1.

Operating on tight timelines (2.5 months total for process development, implementation and final decision making), process features included a formal communication plan, clearly defined, weighted assessment criteria linked to the strategic priorities of the health authority, a proposal rating tool and use of a standard business case template. The research team provided the working committee with a straw man set of criteria that were adapted and refined through several iterations. The criteria and rating tool are presented in Table 2. Criteria were weighted by a set of internal stakeholders through a simple point-allocation method. This involved asking approximately 20 managers and clinical leaders within $\mathrm{VCH}$ who were involved in the Vancouver Communities Division to allocate 100 points across the established criteria. A mean for each criteria was then calculated which was used as the weight in deriving the benefit score.

Managers within Vancouver Communities submitted proposals for disinvestment and then investment to the working committee for assessment and ranking, with recommendations forwarded to the Advisory Panel. As a detailed program evaluation had previously been conducted, managers were intimately aware of the services across the program areas in this division. In some cases literature and other sources of information including benchmarking and practice patterns elsewhere were drawn on to develop proposals. In all cases, the type of evidence base for the given proposal was identified in the business case submission. Areas of care within the

Table 1 Groups and roles

\begin{tabular}{|c|c|}
\hline Groups & Roles \\
\hline $\begin{array}{l}\text { Priority setting working committee (Directors and Clinical } \\
\text { Leads within Vancouver Communities division) }\end{array}$ & $\begin{array}{c}\text { Actual implementation of PBMA, e.g., establishing criteria, deciding on process } \\
\text { guidelines, rating of proposals, recommendations to Advisory Panel }\end{array}$ \\
\hline $\begin{array}{l}\text { PBMA Advisory Panel (mix of Vancouver Communities } \\
\text { personnel and Senior Executive Team members) }\end{array}$ & $\begin{array}{l}\text { Oversight of PBMA implementation, approval of the process guidelines, criteria and } \\
\text { ratings, providing recommendations to the Senior Executive Team }\end{array}$ \\
\hline Senior Executive Team (CEO and direct reports) & $\begin{array}{l}\text { Review of the process recommendations and decisions on these recommendations } \\
\text { (subject to Board approval) }\end{array}$ \\
\hline Research team & $\begin{array}{l}\text { Facilitators, process stewards, non-voting observers at working committee and } \\
\text { advisory panel meetings }\end{array}$ \\
\hline
\end{tabular}




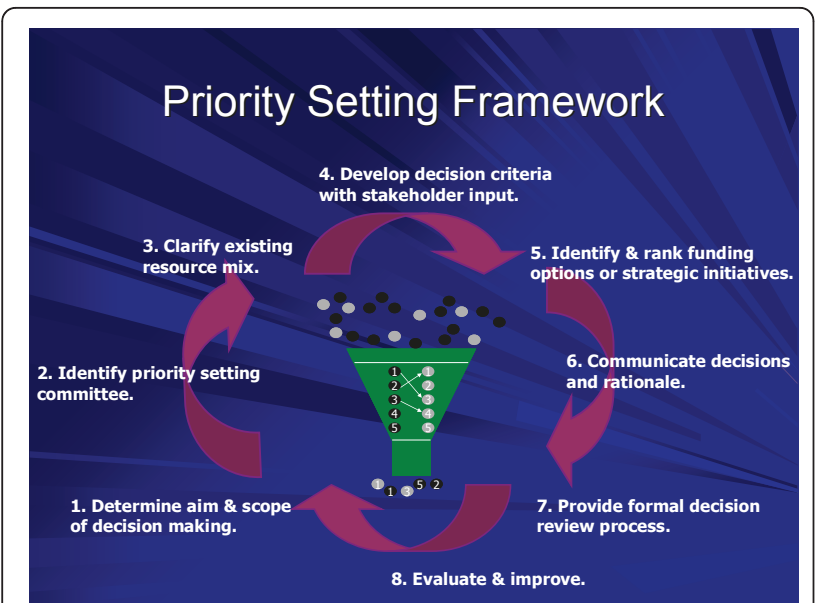

Figure 1 PBMA approach as implemented in $\mathrm{VCH}$

scope of the exercise are listed in Table 3, which constituted just under half of the total budget of the Vancouver Communities division. Issues related to scope are addressed below.

The research team conducted an evaluation of the exercise immediately following announcement of final decisions by Senior Executive. The primary objective was to identify areas of improvement and assess possible expansion of PBMA to other areas within the health authority. Between March 23 and April 13, 2010, 10 decision-makers were interviewed face to face. Potential respondents were purposively selected by the research team to provide representation in terms of background (clinical and management) and level within the organization. The researchers held the identity of the respondents in confidence. The semi-structured interviews were audio taped and a thematic analysis was conducted. The results presented here focus on training, framework implementation, and future opportunities for PBMA within the health authority.

External ethics board approval was not sought for this project, as all of the people involved were health authority decision makers who were acting in the course of their normal duties. Further, the interviews to inform the evaluation were conducted solely to improve future implementation in the health authority.

\section{Results}

The recommendations of the working committee included the implementation of 44 disinvestment initiatives with an annualized value of $\$ 4.9$ million, as well as consideration of possible investments if the realized savings match expectations. These recommendations were approved by the Advisory Panel and then presented to Senior Executive on March 23, 2010. At that meeting, Senior Executive agreed to implement all of the process recommendations regarding disinvestments and to support further development of a limited set of investment options. For the latter, a preliminary list of investment options was established by the working committee for assessment of relative value against remaining disinvestment options that would not be used to meet the deficit. The working committee and Advisory Panel supported this conservative approach prior to receiving approval by the Senior Executive. The working committee in particular felt that expectations would be best held in check by not prematurely introducing a lengthy (and ultimately unrealistic) list of investment options.

The ranked disinvestment initiatives are presented in Table 4 (with actual program names removed), along with preliminary investment options in Table 5. Should further work on investments be pursued, the next step in this work would be to make relative value comparisons of each investment option to the next lowest ranked (i.e., least beneficial) disinvestment option, beyond that which was required to meet the deficit. If an investment option is deemed to be of greater value then the benefit lost by acting on the disinvestment option, a recommendation for resource re-allocation would ensue. Over time, such changes 'at the margin' would lead to improvements in the overall spending based on how well the objectives of the organization (as reflected through the criteria) are being met. As stated above, the primary aim of the exercise was to meet the deficit; changes beyond this were to be considered but were discretionary.

The results from the evaluation interviews are reported for three major themes: training, implementation and future use. Overall feedback on the training provided at the start of the project was positive. The main strengths of the training were that it was: focused (i.e. that it dealt with what was necessary to implement the PBMA process); direct (i.e. that it avoided jargon and was presented clearly and concisely); and relevant (i. e. it incorporated the use of examples that were meaningful to the participants). One concern that was raised with respect to training was that some participants had a misunderstanding early on about what specifically PBMA would do. That is, some of the participants expected PBMA to take the form of program evaluation whereby a ranking of all programs within Vancouver Communities would result. Additional time was required during training to explain that PBMA focuses on changes to services and the marginal or incremental benefit gain (or loss) from implementing a specific proposal. This has important ramifications because the focus of PBMA is on shifting the levels of service as opposed to complete deletion or novel introduction of a program (although in the extreme a shift in level could indeed be to fully eliminate or introduce a program). In 


\begin{tabular}{|c|c|c|c|c|c|c|c|c|c|c|c|}
\hline \multirow[t]{2}{*}{ DOMAIN } & \multirow{2}{*}{$\begin{array}{l}\text { Domain } \\
\text { Weights }\end{array}$} & \multirow[t]{2}{*}{ CRITERIA } & \multirow[t]{2}{*}{ DEFINITION } & \multirow{2}{*}{$\begin{array}{l}\text { Criteria } \\
\text { Weight }\end{array}$} & \multicolumn{7}{|c|}{ RATING SCALE } \\
\hline & & & & & -3 & -2 & -1 & 0 & 1 & 2 & 3 \\
\hline & & $\begin{array}{l}\text { Alignment to } \\
\text { Mandate }\end{array}$ & $\begin{array}{l}\text { 1) The service is directly } \\
\text { related to health care or } \\
\text { preventative health }\end{array}$ & & & & & & & & \\
\hline & & & $\begin{array}{l}\text { 2) The service is not } \\
\text { provided by another } \\
\text { organization outside } \mathrm{VCH}\end{array}$ & 15 & $\begin{array}{l}\text { Strong } \\
\text { alignment with } \\
\text { mandate (for } \\
\text { releases) }\end{array}$ & $\begin{array}{l}\text { Moderate } \\
\text { alignment with } \\
\text { mandate (for } \\
\text { releases) }\end{array}$ & $\begin{array}{l}\text { Weak } \\
\text { alignment with } \\
\text { mandate (for } \\
\text { releases) }\end{array}$ & $\begin{array}{l}\text { No alignment } \\
\text { with mandate } \\
\text { (for releases or } \\
\text { investments) }\end{array}$ & $\begin{array}{c}\text { Weak } \\
\text { alignment with } \\
\text { mandate (for } \\
\text { invests) }\end{array}$ & $\begin{array}{l}\text { Moderate } \\
\text { alignment with } \\
\text { mandate (for } \\
\text { invests) }\end{array}$ & $\begin{array}{c}\text { Strong } \\
\text { alignment with } \\
\text { mandate (for } \\
\text { invests) }\end{array}$ \\
\hline & & & $\begin{array}{l}\text { 3) The service is not the } \\
\text { responsibility of an } \\
\text { organization outside } \mathrm{VCH}\end{array}$ & & & & & & & & \\
\hline \multirow[t]{6}{*}{$\begin{array}{l}\text { Strategic } \\
\text { alignment }\end{array}$} & 30 & $\begin{array}{l}\text { Efficiency, } \\
\text { Effectiveness } \\
\text { and } \\
\text { Appropriate- } \\
\text { ness }\end{array}$ & $\begin{array}{l}\text { 1) Optimal use of } \\
\text { resources to yield } \\
\text { maximum benefits and } \\
\text { results, }\end{array}$ & & & & & & & & \\
\hline & & & $\begin{array}{l}\text { 2) Care that is known to } \\
\text { achieve intended } \\
\text { outcomes }\end{array}$ & 5 & $\begin{array}{l}\text { Goes against } \\
\text { four or five of } \\
\text { the five } \\
\text { objectives }\end{array}$ & $\begin{array}{l}\text { Goes against } \\
\text { two or three } \\
\text { of the five } \\
\text { objectives }\end{array}$ & $\begin{array}{l}\text { Goes against } \\
\text { one of the five } \\
\text { objectives }\end{array}$ & No net impact & $\begin{array}{l}\text { Supports one } \\
\text { of the five } \\
\text { objectives }\end{array}$ & $\begin{array}{l}\text { Supports two } \\
\text { or three of the } \\
\text { five objectives }\end{array}$ & $\begin{array}{l}\text { Supports four } \\
\text { or five of the } \\
\text { five objectives }\end{array}$ \\
\hline & & & $\begin{array}{l}\text { 3) Care provided is } \\
\text { evidence based and } \\
\text { specific to individual } \\
\text { clinical needs }\end{array}$ & & & & & & & & \\
\hline & & & $\begin{array}{l}\text { 4) Promote wellness \& } \\
\text { prevention initiatives }\end{array}$ & & & & & & & & \\
\hline & & & $\begin{array}{l}\text { 5) Support clients at } \\
\text { home/returning home or } \\
\text { self management }\end{array}$ & & & & & & & & \\
\hline & & Access & $\begin{array}{l}\text { Impact on timely access } \\
\text { to appropriate health } \\
\text { care services for defined } \\
\text { population(s). Note: the } \\
\text { 'defined populations' are } \\
\text { those using the services } \\
\text { affected by the proposed } \\
\text { changes. }\end{array}$ & 5 & $\begin{array}{l}\text { Significant } \\
\text { (more than } \\
10 \% \text { ) } \\
\text { worsening of } \\
\text { the waiting } \\
\text { times for more } \\
\text { than } 20 \% \text { of } \\
\text { the population } \\
\text { or complete } \\
\text { closure of a } \\
\text { service }\end{array}$ & $\begin{array}{c}\text { Significant } \\
\text { (more than } \\
10 \% \text { ) } \\
\text { worsening of } \\
\text { the waiting } \\
\text { times } 10 \% \text { to } \\
20 \% \text { of the } \\
\text { population or } \\
\text { closure of a } \\
\text { service for } \\
\text { more than } \\
25 \% \text { of the } \\
\text { time }\end{array}$ & $\begin{array}{l}\text { Significant } \\
\text { (more than } \\
10 \% \text { ) } \\
\text { worsening of } \\
\text { the waiting } \\
\text { times for less } \\
\text { than } 10 \% \text { of } \\
\text { the population } \\
\text { or closure of a } \\
\text { service for less } \\
\text { than } 25 \% \text { of } \\
\text { the time }\end{array}$ & No impact & $\begin{array}{c}\text { Significant } \\
\text { (more than } \\
10 \% \text { ) } \\
\text { improvement } \\
\text { of the waiting } \\
\text { times for less } \\
\text { than } 10 \% \text { of } \\
\text { the population } \\
\text { or expansion } \\
\text { of hours by } \\
\text { less than } 25 \%\end{array}$ & $\begin{array}{c}\text { Significant } \\
\text { (more than } \\
10 \% \text { ) } \\
\text { improvement } \\
\text { of the waiting } \\
\text { times for } 10 \% \\
\text { to } 20 \% \text { of the } \\
\text { population or } \\
\text { expansion of } \\
\text { the hours by } \\
\text { more than } \\
25 \%\end{array}$ & $\begin{array}{c}\text { Significant } \\
\text { (more than } \\
10 \% \text { ) } \\
\text { improvement } \\
\text { of the waiting } \\
\text { times for more } \\
\text { than } 20 \% \text { of } \\
\text { the population } \\
\text { or opening of } \\
\text { a new service } \\
\text { facility (not a } \\
\text { replacement) }\end{array}$ \\
\hline
\end{tabular}


Table 2 Criteria and rating scale* (Continued)

\begin{tabular}{|c|c|c|c|c|c|c|c|c|c|c|c|}
\hline & & $\begin{array}{l}\text { Flow/ } \\
\text { Integration }\end{array}$ & $\begin{array}{l}\text { Impact on the } \\
\text { coordination of health } \\
\text { care services among } \\
\text { programs to ensure flow } \\
\text { and continuity of care } \\
\text { from the patient's } \\
\text { perspective (improve flow } \\
\text { transitions) }\end{array}$ & 5 & $\begin{array}{l}\text { Negative } \\
\text { impact on } \\
\text { continuity for } \\
\text { more than } \\
20 \% \text { of clients } \\
\text { or significant } \\
\text { worsening for } \\
\text { some patients }\end{array}$ & $\begin{array}{l}\text { Negative } \\
\text { impact on } \\
\text { continuity for } \\
10 \% \text { to } 20 \% \text { of } \\
\text { clients }\end{array}$ & $\begin{array}{l}\text { Negative } \\
\text { impact on } \\
\text { continuity for } \\
5 \% \text { to } 10 \% \text { of } \\
\text { clients }\end{array}$ & $\begin{array}{l}\text { Impact on less } \\
\text { than } 5 \% \text { of } \\
\text { clients }\end{array}$ & $\begin{array}{l}\text { Improvement } \\
\text { in continuity } \\
\text { for } 5 \% \text { to } 10 \% \\
\text { of clients }\end{array}$ & $\begin{array}{l}\text { Improvement } \\
\text { in continuity } \\
\text { for } 10 \% \text { to } \\
20 \% \text { of clients }\end{array}$ & $\begin{array}{l}\text { Improvement } \\
\text { in continuity } \\
\text { for more than } \\
20 \% \text { of } \\
\text { patients or } \\
\text { significant } \\
\text { improvement } \\
\text { for some } \\
\text { clients }\end{array}$ \\
\hline \multirow[t]{5}{*}{ Health Impact } & \multirow[t]{5}{*}{45} & $\begin{array}{l}\text { Numbers } \\
\text { affected }\end{array}$ & $\begin{array}{l}\text { Number of individuals } \\
\text { affected by the proposed } \\
\text { change }\end{array}$ & 8 & $\begin{array}{c}\text { More than } \\
1500 \text { have less } \\
\text { services }\end{array}$ & $\begin{array}{c}251 \text { to } 1500 \\
\text { have less } \\
\text { services }\end{array}$ & $\begin{array}{l}1 \text { to } 250 \text { have } \\
\text { less services }\end{array}$ & 0 & $\begin{array}{l}1 \text { to } 250 \text { have } \\
\text { more services }\end{array}$ & $\begin{array}{l}251 \text { to } 1500 \\
\text { have more } \\
\text { services }\end{array}$ & $\begin{array}{l}\text { More than } \\
1500 \text { have } \\
\text { more services }\end{array}$ \\
\hline & & Equity & $\begin{array}{l}\text { Impact on the health } \\
\text { status of recognized } \\
\text { groups where there is a } \\
\text { known health status gap. }\end{array}$ & 10 & $\begin{array}{l}\text { More than } \\
50 \% \text { of those } \\
\text { affected are in } \\
\text { the most } \\
\text { disadvantaged } \\
\text { groups } \\
\text { (releases) }\end{array}$ & $\begin{array}{l}\text { More than } \\
50 \% \text { of those } \\
\text { affected are in } \\
\text { moderately } \\
\text { disadvantaged } \\
\text { groups } \\
\text { (releases) }\end{array}$ & $\begin{array}{l}10 \% \text { to } 50 \% \text { of } \\
\text { those affected } \\
\text { are in the } \\
\text { most } \\
\text { disadvantaged } \\
\text { groups } \\
\text { (releases) }\end{array}$ & $\begin{array}{l}\text { Less than } 50 \% \\
\text { of those } \\
\text { affected are in } \\
\text { moderately } \\
\text { disadvantaged } \\
\text { groups } \\
\text { (releases or } \\
\text { investments) }\end{array}$ & $\begin{array}{l}10 \% \text { to } 50 \% \text { of } \\
\text { those affected } \\
\text { are in the } \\
\text { most } \\
\text { disadvantaged } \\
\text { groups } \\
\text { (invests) }\end{array}$ & $\begin{array}{l}\text { More than } \\
50 \% \text { of those } \\
\text { affected are in } \\
\text { moderately } \\
\text { disadvantaged } \\
\text { groups } \\
\text { (invests) }\end{array}$ & $\begin{array}{l}\text { More than } \\
50 \% \text { of those } \\
\text { affected are in } \\
\text { the most } \\
\text { disadvantaged } \\
\text { groups } \\
\text { (investments) }\end{array}$ \\
\hline & & $\begin{array}{c}\text { Significance of } \\
\text { impact }\end{array}$ & $\begin{array}{l}\text { Impact on clinical } \\
\text { outcomes for the patient/ } \\
\text { client, including risk of } \\
\text { adverse events, as } \\
\text { compared to current } \\
\text { practice/service. }\end{array}$ & 11 & $\begin{array}{l}\text { Significant } \\
\text { negative } \\
\text { impact (either } \\
\text { more than } \\
25 \% \text { of } \\
\text { affected clients } \\
\text { suffer negative } \\
\text { effects or } \\
\text { some clients } \\
\text { are } \\
\text { significantly } \\
\text { affected) }\end{array}$ & $\begin{array}{l}\text { Moderate } \\
\text { negative } \\
\text { impact (10\% } \\
\text { to } 25 \% \text { of } \\
\text { affected clients } \\
\text { suffer negative } \\
\text { effects) }\end{array}$ & $\begin{array}{l}\text { Small negative } \\
\text { impact (5\% to } \\
10 \% \text { of } \\
\text { affected clients } \\
\text { suffer some } \\
\text { negative } \\
\text { effects) }\end{array}$ & $\begin{array}{l}\text { Less than } 5 \% \\
\text { of affected } \\
\text { clients } \\
\text { experience any } \\
\text { changes in } \\
\text { satisfaction of } \\
\text { safety }\end{array}$ & $\begin{array}{l}\text { Small positive } \\
\text { impact (5\% to } \\
10 \% \text { of } \\
\text { affected clients } \\
\text { enjoy some } \\
\text { positive } \\
\text { effects) }\end{array}$ & $\begin{array}{l}\text { Moderate } \\
\text { positive impact } \\
\text { (10\% to } 25 \% \\
\text { of affected } \\
\text { clients enjoy } \\
\text { positive } \\
\text { effects) }\end{array}$ & $\begin{array}{l}\text { Significant } \\
\text { positive impact } \\
\text { (either more } \\
\text { than } 25 \% \text { of } \\
\text { affected clients } \\
\text { enjoy positive } \\
\text { effects or } \\
\text { some clients } \\
\text { are } \\
\text { significantly } \\
\text { affected) }\end{array}$ \\
\hline & & $\begin{array}{l}\text { Health } \\
\text { promotion and } \\
\text { disease } \\
\text { prevention }\end{array}$ & $\begin{array}{l}\text { Impact on illness and/or } \\
\text { injury prevention, well- } \\
\text { being and harm } \\
\text { reduction as measured } \\
\text { by projected longer term } \\
\text { improvements in health }\end{array}$ & 8 & $\begin{array}{l}\text { Significant } \\
\text { negative } \\
\text { impact on } \\
\text { burden of } \\
\text { disease }\end{array}$ & $\begin{array}{l}\text { Moderate } \\
\text { negative } \\
\text { impact on } \\
\text { burden of } \\
\text { disease }\end{array}$ & $\begin{array}{l}\text { Small negative } \\
\text { impact on } \\
\text { burden of } \\
\text { disease }\end{array}$ & $\begin{array}{l}\text { No impact on } \\
\text { burden of } \\
\text { disease }\end{array}$ & $\begin{array}{l}\text { Small positive } \\
\text { impact on } \\
\text { burden of } \\
\text { disease }\end{array}$ & $\begin{array}{c}\text { Moderate } \\
\text { positive impact } \\
\text { on burden of } \\
\text { disease }\end{array}$ & $\begin{array}{c}\text { Significant } \\
\text { positive impact } \\
\text { on burden of } \\
\text { disease }\end{array}$ \\
\hline & & $\begin{array}{c}\text { Client } \\
\text { experience }\end{array}$ & $\begin{array}{l}\text { Impact on safety, } \\
\text { effectiveness, and client } \\
\text { experience of health } \\
\text { service(s) provided. }\end{array}$ & 8 & $\begin{array}{l}\text { Negative } \\
\text { impact (safety } \\
\text { or satisfaction) } \\
\text { for more than } \\
20 \% \text { of } \\
\text { affected clients }\end{array}$ & $\begin{array}{l}\text { Negative } \\
\text { impact (safety } \\
\text { or satisfaction) } \\
\text { for } 10 \% \text { to } \\
20 \% \text { of } \\
\text { affected clients }\end{array}$ & $\begin{array}{c}\text { Negative } \\
\text { impact (safety } \\
\text { or satisfaction) } \\
\text { for } 5 \% \text { to } 10 \% \\
\text { of affected } \\
\quad \text { clients }\end{array}$ & $\begin{array}{l}\text { Less than } 5 \% \\
\text { of affected } \\
\text { clients } \\
\text { experience any } \\
\text { changes in } \\
\text { satisfaction of } \\
\text { safety }\end{array}$ & $\begin{array}{l}\text { Positive impact } \\
\text { (safety or } \\
\text { satisfaction) for } \\
5 \% \text { to } 10 \% \text { of } \\
\text { affected clients }\end{array}$ & $\begin{array}{l}\text { Positive impact } \\
\text { (safety or } \\
\text { satisfaction) for } \\
10 \% \text { to } 20 \% \text { of } \\
\text { affected clients }\end{array}$ & $\begin{array}{l}\text { Positive impact } \\
\text { (safety or } \\
\text { satisfaction) for } \\
\text { more than } \\
20 \% \text { of } \\
\text { affected clients }\end{array}$ \\
\hline
\end{tabular}


Table 2 Criteria and rating scale* (Continued)

\begin{tabular}{|c|c|c|c|c|c|c|c|c|c|c|c|}
\hline & & $\begin{array}{l}\text { Workplace } \\
\text { environment }\end{array}$ & $\begin{array}{l}\text { Impact on workplace } \\
\text { environment including } \\
\text { morale, tools and } \\
\text { equipment, personal and } \\
\text { professional growth and } \\
\text { teamwork }\end{array}$ & 5 & $\begin{array}{l}\text { Significant } \\
\text { negative } \\
\text { impact on } \\
\text { recruitment } \\
\text { and retention } \\
\text { or on stress } \\
\text { leave }\end{array}$ & $\begin{array}{l}\text { Moderate } \\
\text { negative } \\
\text { impact on } \\
\text { recruitment } \\
\text { and retention } \\
\text { or on stress } \\
\text { leave }\end{array}$ & $\begin{array}{l}\text { Small negative } \\
\text { impact on } \\
\text { recruitment } \\
\text { and retention } \\
\text { or on stress } \\
\quad \text { leave }\end{array}$ & No impact & $\begin{array}{l}\text { Small positive } \\
\text { impact on } \\
\text { recruitment } \\
\text { and retention } \\
\text { or on stress } \\
\quad \text { leave }\end{array}$ & $\begin{array}{l}\text { Moderate } \\
\text { positive impact } \\
\text { on recruitment } \\
\text { and retention } \\
\text { or on stress } \\
\quad \text { leave }\end{array}$ & $\begin{array}{c}\text { Significant } \\
\text { positive impact } \\
\text { on recruitment } \\
\text { and retention } \\
\text { or on stress } \\
\text { leave }\end{array}$ \\
\hline \multirow[t]{3}{*}{$\begin{array}{l}\text { Organizational } \\
\text { Impact }\end{array}$} & 25 & $\begin{array}{l}\text { Innovation and } \\
\text { knowledge } \\
\text { transfer }\end{array}$ & $\begin{array}{l}\text { Impact on the generation } \\
\text { and/or application of } \\
\text { new knowledge/practice. }\end{array}$ & 5 & $\begin{array}{c}\text { Significant } \\
\text { negative } \\
\text { impact on the } \\
\text { generation or } \\
\text { application of } \\
\text { new } \\
\text { knowledge/ } \\
\text { practice }\end{array}$ & $\begin{array}{c}\text { Moderate } \\
\text { negative } \\
\text { impact on the } \\
\text { generation or } \\
\text { application of } \\
\text { new } \\
\text { knowledge/ } \\
\text { practice }\end{array}$ & $\begin{array}{l}\text { Small negative } \\
\text { impact on the } \\
\text { generation or } \\
\text { application of } \\
\text { new } \\
\text { knowledge/ } \\
\text { practice }\end{array}$ & No impact & $\begin{array}{c}\text { Small positive } \\
\text { impact on the } \\
\text { generation or } \\
\text { application of } \\
\text { new } \\
\text { knowledge/ } \\
\text { practice }\end{array}$ & $\begin{array}{c}\text { Moderate } \\
\text { positive impact } \\
\text { on the } \\
\text { generation or } \\
\text { application of } \\
\text { new } \\
\text { knowledge/ } \\
\text { practice }\end{array}$ & $\begin{array}{c}\text { Significant } \\
\text { positive impact } \\
\text { on the } \\
\text { generation or } \\
\text { application of } \\
\text { new } \\
\text { knowledge/ } \\
\text { practice }\end{array}$ \\
\hline & & Implementation & $\begin{array}{l}\text { Challenges to the } \\
\text { implementation of } \\
\text { proposed initiative (or } \\
\text { reversal) }\end{array}$ & 5 & $\begin{array}{l}\text { Significant } \\
\text { political } \\
\text { resistance and } \\
\text { change would } \\
\text { be very } \\
\text { difficult to } \\
\text { undo }\end{array}$ & $\begin{array}{l}\text { Significant } \\
\text { political } \\
\text { resistance but } \\
\text { change could } \\
\text { be undone }\end{array}$ & $\begin{array}{l}\text { Moderate } \\
\text { political } \\
\text { resistance } \\
\text { expected }\end{array}$ & $\begin{array}{l}\text { No political } \\
\text { impact }\end{array}$ & $\begin{array}{l}\text { Moderate } \\
\text { political } \\
\text { support } \\
\text { expected }\end{array}$ & $\begin{array}{l}\text { Strong political } \\
\text { support } \\
\text { expected }\end{array}$ & $\begin{array}{l}\text { Strong political } \\
\text { support and } \\
\text { change can be } \\
\text { reversed }\end{array}$ \\
\hline & & $\begin{array}{l}\text { Downstream } \\
\text { impact on } \\
\text { service } \\
\text { utilization }\end{array}$ & $\begin{array}{l}\text { Impact of the proposed } \\
\text { change on future use of } \\
\text { health care services }\end{array}$ & 10 & $\begin{array}{c}\text { Significant } \\
\text { increase in } \\
\text { future use of } \\
\text { health care } \\
\text { services }\end{array}$ & $\begin{array}{l}\text { Moderate } \\
\text { increase in } \\
\text { future use of } \\
\text { health care } \\
\text { services }\end{array}$ & $\begin{array}{l}\text { Small increase } \\
\text { in future use } \\
\text { of health care } \\
\text { services }\end{array}$ & $\begin{array}{l}\text { No impact on } \\
\text { future use of } \\
\text { services }\end{array}$ & $\begin{array}{c}\text { Small decrease } \\
\text { in future use } \\
\text { of health care } \\
\text { services }\end{array}$ & $\begin{array}{l}\text { Moderate } \\
\text { decrease in } \\
\text { future use of } \\
\text { health care } \\
\text { services }\end{array}$ & $\begin{array}{l}\text { Significant } \\
\text { decrease in } \\
\text { future use of } \\
\text { health care } \\
\text { services }\end{array}$ \\
\hline
\end{tabular}

*This table describes the overall domain, criteria, brief definition of criteria, weighting of criteria and rating scale for assessing each proposal. 
Table 3 Programs in scope of exercise

\begin{tabular}{|c|c|c|c|}
\hline & Direct Services In Scope & Contracted Services In Scope & Total In Scope \\
\hline Prevention and Promotion & $18,964,284$ & 50,296 & $19,014,580$ \\
\hline \multicolumn{4}{|l|}{ Primary Care } \\
\hline Primary Care & $15,764,244$ & 478,581 & $16,242,825$ \\
\hline Adults and Older Adults & $32,729,138$ & $22,347,397$ & $55,076,536$ \\
\hline Alcohol and Drug & $21,211,299$ & $20,965,473$ & $42,176,772$ \\
\hline Mental Health & $39,290,286$ & $44,729,076$ & $84,019,362$ \\
\hline Special Care Contracts & & $2,153,626$ & $2,153,626$ \\
\hline Total Health Serv. and Supplies & $127,959,251$ & $90,724,449$ & $218,683,700$ \\
\hline Program Supports & $18,173,063$ & 0 & $18,173,063$ \\
\hline Total Van. Comm. Hlth Services & $146,132,314$ & $90,724,449$ & $236,856,763$ \\
\hline
\end{tabular}

moving forward, it was felt that two key aspects of the training should be emphasized: the use of real life examples in demonstrating the potential impact of PBMA and establishing that PBMA is principally about changes to services at the margin.

All respondents were extremely positive about framework implementation and resulting recommendations. There was recognition amongst respondents that the role of PBMA was primarily limited to the development of a plan to address the expected deficit. However, in that light, PBMA was viewed as being more robust then previous resource allocation processes that relied on historical patterns and/or politics. This was largely due to a well-defined set of decision criteria and high degree of process transparency. There was also clear recognition of the potential value of developing investment proposals and of considering re-allocations beyond what was required to balance the budget. Overall the results were seen as an improvement from previous activity for two main reasons: first, the marginal approach was seen to have led in many cases to a different set of proposals than what would have been otherwise considered; and second, the process enabled consideration of real changes to services instead of an ongoing search for greater efficiency. Open consideration of changes to services created a new range of alternative proposals to address the deficit problem.

A third major theme from the interviews related to future opportunities for the use of this priority setting process in the health authority. The clear message from the interviews was that PBMA is a desirable process and wider rollout should occur within $\mathrm{VCH}$. This was based on three main points. First, the process provides a measurement methodology for the management of resources that was demonstrated to be effective in the Vancouver Communities pilot. Second, respondents felt that the process would lead to a more consistent approach to resource management across the entire organization. Third, because the process allows for marginal analysis across disparate services, the process creates opportunities for sharing of knowledge across the organization. It was felt that the rating process, specifically, would provide opportunities to exchange information between parts of the organization that do not tend to work together but whose decisions impact each other.

\section{Discussion}

The logic of PBMA is straightforward: when resources are limited, decision makers must look at ways to reallocate within the fixed pot available in order to receive the greatest return on investment. The PBMA process tends to bring a level of rigor and consistency to decision making seldom found within a historical and/or political allocation model [4]. The approach has been implemented in many organizations across countries [5], and where formal evaluation has taken place, decision makers almost universally indicate a desire to continue on with the process in future years subject to specific 
Table 4 Disinvestment options by weighted score

\begin{tabular}{|c|c|c|c|}
\hline Disinvestment Opportunity & Weighted Score* & Annualized Savings** & VCH FTE impacted \\
\hline 1 & 0.44 & $\$ 291,450$ & 0.00 \\
\hline 2 & 0.00 & $\$ 76,690$ & -0.80 \\
\hline 3 & 0.00 & $\$ 42,686$ & -1.00 \\
\hline 4 & 0.00 & $\$ 182,439$ & 0.00 \\
\hline 5 & 0.00 & $\$ 21,588$ & -0.50 \\
\hline 6 & 0.00 & $\$ 15,494$ & -0.40 \\
\hline 7 & 0.00 & $\$ 40,000$ & -0.60 \\
\hline 8 & 0.00 & $\$ 112,395$ & 0.00 \\
\hline 9 & 0.00 & $\$ 17,741$ & -0.44 \\
\hline 10 & 0.00 & $\$ 48,400$ & -0.50 \\
\hline 11 & 0.00 & $\$ 50,700$ & -1.00 \\
\hline 12 & 0.00 & $\$ 57,886$ & -1.00 \\
\hline 13 & 0.00 & $\$ 77,000$ & -1.00 \\
\hline 14 & -0.25 & $\$ 119,224$ & -1.00 \\
\hline 15 & -0.31 & $\$ 48,215$ & -1.00 \\
\hline 16 & -0.31 & $\$ 53,956$ & -0.70 \\
\hline 17 & -0.36 & $\$ 120,000$ & -1.00 \\
\hline 18 & -0.50 & $\$ 53,723$ & -0.60 \\
\hline 19 & -0.51 & $\$ 42,000$ & -0.50 \\
\hline 20 & -0.53 & $\$ 28,523$ & -0.16 \\
\hline 21 & -0.54 & $\$ 100,906$ & -0.90 \\
\hline 22 & -0.56 & $\$ 50,729$ & -0.10 \\
\hline 23 & -0.58 & $\$ 96,498$ & -1.30 \\
\hline 24 & -0.58 & $\$ 240,630$ & -2.80 \\
\hline 25 & -0.62 & $\$ 762,715$ & -15.80 \\
\hline 26 & -0.65 & $\$ 87,635$ & -1.00 \\
\hline 27 & -0.72 & $\$ 64,340$ & -0.80 \\
\hline 28 & -0.73 & $\$ 41,461$ & -0.50 \\
\hline 29 & -0.74 & $\$ 41,897$ & -0.09 \\
\hline 30 & -0.76 & $\$ 295,679$ & 0.00 \\
\hline 31 & -0.83 & $\$ 26,574$ & -0.30 \\
\hline 32 & -0.86 & $\$ 60,000$ & 0.00 \\
\hline 33 & -0.87 & $\$ 88,776$ & 0.00 \\
\hline 34 & -0.92 & $\$ 21,000$ & 0.00 \\
\hline 35 & -0.92 & $\$ 70,605$ & -2.00 \\
\hline 36 & -0.96 & $\$ 23,094$ & 0.00 \\
\hline 37 & -1.00 & $\$ 58,882$ & 0.00 \\
\hline 38 & -1.04 & $\$ 397,352$ & 0.00 \\
\hline 39 & -1.04 & $\$ 278,784$ & -4.00 \\
\hline 40 & -1.14 & $\$ 120,000$ & 0.00 \\
\hline 41 & -1.16 & $\$ 68,000$ & 0.00 \\
\hline 42 & -1.41 & $\$ 134,500$ & -2.80 \\
\hline 43 & -1.45 & $\$ 200,000$ & 0.00 \\
\hline 44 & -1.64 & $\$ 82,000$ & 0.00 \\
\hline TOTAL & & $\$ 4,912,167$ & -44.59 \\
\hline
\end{tabular}

${ }^{*}$ A positive weighted score indicates that acting on the disinvestment would result in the organization moving closer to its objectives; zero weighted score indicates no impact on organizational objectives; a negative weighted score indicates that implementation would move the organization away from its objectives. **If all savings were realized as indicated, the deficit would be met by opportunity \#42, leaving two proposals and approximately \$282,000 for consideration against the investment opportunities. 
Table 5 Investment options by weighted score

\begin{tabular}{ccc}
\hline $\begin{array}{c}\text { Investment } \\
\text { Opportunity* }\end{array}$ & $\begin{array}{c}\text { Weighted } \\
\text { Score** }\end{array}$ & $\begin{array}{c}\text { Annualized } \\
\text { Investment*** }\end{array}$ \\
\hline 1 & 2.07 & $\$ 95,000$ \\
\hline 2 & 1.87 & $\$ 69,600$ \\
\hline 3 & 1.72 & $\$ 10,000$ \\
\hline 4 & 1.43 & $\$ 45,000$ \\
\hline 5 & 0.44 & $\$ 310,000$ \\
\hline TOTAL & & $\$ 529,600$ \\
\hline
\end{tabular}

*These proposals were put forward for consideration but were not acted upon immediately.

**Higher weighted scores indicate greater benefit gain by acting on the investment opportunity.

***If marginal analysis was to proceed beyond deficit elimination, re-allocation from disinvestment 43 to investments 1 to 3 would be recommended, as the benefit loss on the disinvestment is less then the potential benefit gained through these investments. Investment opportunity 4 and 5 would not proceed as the expected benefit gain is less then the benefit loss of disinvestment 44 .

refinement [6]. Such support from the end-users is likely due at least in part to building in process characteristics such as transparency and use of best available evidence, both known to be key elements of fairness [7].

In the case of $\mathrm{VCH}, \mathrm{PBMA}$ was implemented in a single division with a focus on primary care, community care and public health. To our knowledge few PBMA studies have been conducted in these areas. The primary aim of the exercise was to bring expenditure in line with available funds. The decision to use PBMA and to focus on Vancouver Communities as a pilot was the sole discretion of the Senior Executive of the health authority. As part of the PBMA process, decision makers must determine what activities are 'in scope' and what are 'out of scope'. In this case a little over half the Vancouver Communities budget was deemed to be out of scope for a variety of reasons including that some programs were ring-fenced, some programs received direct Ministry of Health funds and thus could not be challenged in this process, and in some cases programs were undergoing other separate reviews to address their deficit challenges. It was the working committee comprised of Vancouver Communities personnel that provided the recommendation for what was in and out of scope, and the deficit target was set accordingly. Some early discussion centered on the difficulties of making decisions in community services without acute services being represented at the table. Being explicit about this ensured that as proposals came forward, appropriate discussion with acute-based counterparts took place and generally it was felt that 'cost-shifts' from one part of the organization to another were avoided. Overall the process was viewed favorably by the end-users and the primary objective was met.

Nonetheless, one might anticipate at least three challenges to what was done with PBMA at VCH. First, as the timeline was very tight, proposal development may not have been as evidence based as one would hope. This was likely the case, although the application was at the level of managers and directors who have intimate knowledge of the programs under consideration. The leap was in drawing on evidence to support proposals for changes to existing services and as would be expected in some cases research evidence was available and in other cases 'softer' forms of evidence were relied upon. As reasonable evidence is a contributor to process fairness, one could argue that this process was not as fair as might be the case had longer timelines be in play and a stronger evidence base was sought. Ideally, managers and clinical leaders would receive support (either external from university-based researchers or internal from decision support personnel) to review the range of evidence for any given proposal in as thorough a manner as is possible given limited resources and time. Second, PBMA may not have lived up to its name because a formal re-allocation exercise did not immediately follow the allocation of agreed disinvestment proposals to the deficit. However, while the goal of PBMA is always to go deeper into the margin to elicit options for relative value assessment, it would not be correct to suggest that re-allocation did not occur in VCH. Disinvestment proposals were acted upon, with the released resources shifted to the corporate bottom line. That is, the opportunity cost of the disinvestments were assessed and it was felt that the benefit gain of these programs could be foregone in view of meeting the organization's budget requirements. In addition, all stakeholders expressed a desire to move forward with comparing the investment options to remaining (and perhaps additional) disinvestment options once the dust had settled. Third, it is not possible to know if the 'right' decisions were made with respect to disinvestment. Clearly the decision makers felt that better decisions were made then had the process not been used, but this is only a proxy of the true impact. In the absence of a real-world control, which would unlikely be plausible, one cannot be sure that what was done was right. Simply put, this is the reality of uncertainty in health care decision-making.

More generally, despite success across different settings, it is clear that the biggest stumbling block of PBMA is that which is at the very essence of choice making in health care: how to identify disinvestments alongside options for investment [3]. In this, PBMA stands no different then any other resource management tool. In order for 'success' to be achieved, decision makers must be 'bought in' to acceptance of scarcity and the need to assess options for change, there must be strong leadership, and a high level of trust must exist between managers and clinicians. These are but a few key organizational attributes found in the literature that 
can help envisage the outcome of a given priority setting exercise. But is that enough? Is it the case that an external impetus such as a projected deficit is required in order to achieve disinvestment targets?

For the exercise reported herein, the primary aim was to implement a more rigorous, criteria-based process to achieve a disinvestment target based on a projected deficit for the Vancouver Communities division. Thus success in this project can be measured against nothing less then whether this was achieved. That the working group went further to produce more disinvestment options then the deficit called for perhaps suggests that the decision makers had bought in to the principle of PBMA as a re-allocation tool. Those interviewed suggested that approaching programs for disinvestment at the margin resulted in a different set of options then would have resulted through standard program evaluation (and undoubtedly different then across the board percentage cuts). So while there was pain in the cuts, it was collectively held that what was put forward was the least painful set of options (as measured against the objectives of the organization which were reflected in the criteria). At the same time, there can be no denying that the external fiscal impetus 'forced their hand'. It seems that the decision makers got to a different place then they would have had they not implemented PBMA but it is not clear that the decision makers would have engaged in a new method of priority setting had there not been an external impetus. In $\mathrm{VCH}$, deficits had been projected in previous years but the difference this year, it would seem, was a clear government directive of no bailouts. So strictly speaking it was not just the external impetus of a fiscal constraint but the external political will to not 'allow' deficits to stand, which was very different then previous years.

Importantly, regardless of the fiscal driver, the 'selling point' of PBMA must remain as a process that can guide decision making towards optimal allocation of limited resources. Put another way, proactive resource management requires continual assessment of existing services vis-à-vis new investment options and where the relative value of the latter outweighs the former resources should be shifted accordingly [8]. This is the case whether there is a deficit, a surplus, or the organization is in a neutral budget state. This is also the case whether PBMA is being considered or some other framework or process is taken up to assist decision makers in resource allocation. Thus in response to the above question, based on our own experience and what is reported in the literature, our view is that it is not necessary to have an external fiscal driver in play but at the same time it can serve as a very helpful lever.

One question for $\mathrm{VCH}$ is how to proceed so that the success within Vancouver Communities can be built upon in other areas while also mitigating potential challenges. In our view, major gains in terms of shifting resources to better meet organizational objectives is best achieved through systematic application of the framework across divisions. In that, several points should be considered. First, the willingness of decision-makers to participate depends on their trust in the process. If the only perceived outcome is a likely loss of resources, decision-makers may be reticent to participate and no process can overcome a 'forced participation'. This relates to what Jan calls 'credible commitment' [9]. Second, as the use of PBMA widens, more disparate services will be included in the process (eventually including a mix of acute care and population health services). As others have found, this is the real raison d'etre of multi-criteria decision analysis as it provides a method of assessment that relates to the many different (and at times competing) objectives of the decision maker [10]. Finally, there is always a risk of over reliance on the actual rating score for each proposal. The assessments that lead to these ratings, and the underlying assumptions, should always be critically analyzed. As was done in the exercise described herein, the quantitative assessment can serve as the basis for consensus decision-making.

A final thought for further rollout within $\mathrm{VCH}$ is to highlight the importance of the sequential buy-in that took place in the Vancouver Communities exercise. Because the training was viewed favorably there was early buy-in for the process. Then, because of broad participation in criteria development, there was buy-in for the notion of how 'benefit' would be defined. Next, there was buy-in into the marginal approach to proposal development and assessment. And finally, building on the previous steps, there was buy-in into the rating of proposals as well as the final rankings. In the end, this led to a plan that had consensus approval of the working committee. Engagement by the Advisory Panel early on and throughout the process ensured that there were no surprises at that level. In addition, the Advisory Panel took its role seriously and was able to provide a strategic lens that complemented the operational lens of the working committee. In short, buy-in and building from within can be seen as key strategies for further use of PBMA in $\mathrm{VCH}$ and elsewhere.

\section{Conclusion}

In the end, the potential of moving to an organizationwide application of PBMA in $\mathrm{VCH}$ will hinge most directly on the broader organizational context (e.g., does it have a 'learning culture'), as well as executive endorsement and clinical leadership. In this, if the focus is simply to meet a projected deficit based on explicit criteria, the PBMA process is being sold well short. That PBMA 
can respond should this be the objective was clearly demonstrated in the Vancouver Communities exercise. Case studies both in Canada and elsewhere have demonstrated success in terms of identifying disinvestment options sufficient to meet a budget gap and also enable assessment for resource re-allocation across services. Some stakeholders may view this through the lens of 'winners' and 'losers' but the process should focus on the net impact, in terms of ability to meet system objectives, for the entire population being served. It is with this in mind, regardless of the fiscal reality of the day, that will place decision makers in a position to take up a framework like PBMA to improve resource management activities.

\section{Acknowledgements}

We would like to acknowledge the members of the priority setting working committee in the Vancouver Communities division of Vancouver Coastal Health as well as the members of the priority setting advisory panel that worked on this project. This project was funded by Vancouver Coastal Health. Craig Mitton receives funding from the Michael Smith Foundation for Health Research and Francois Dionne was funded through a Canadian Institutes for Health Research Graduate Studentship.

\section{Author details}

${ }^{1}$ Centre for Clinical Epidemiology and Evaluation, Vancouver Coastal Health Research Institute, Vancouver, Canada. ${ }^{2}$ School of Population and Public Health, University of British Columbia, Vancouver, Canada. ${ }^{3}$ Vancouver Coastal Health, Vancouver, Canada.

\section{Authors' contributions}

$C M$ and FD drafted the paper and participated in study design. RD, DC and SB participated in study design and provided detailed comments on the paper. The authors read and approved the final manuscript.

\section{Competing interests}

The authors declare that there are no competing interests.

Received: 28 September 2010 Accepted: 14 July 2011

Published: 14 July 2011

\section{References}

1. Pearson S, Littlejohns P: Reallocating resources: How should the National Institute for Health and Clinical Excellence guide disinvestment efforts in the National Health Service? J Health Serv Res Policy 2007, 12:160-65.

2. Elshaug AG, Moss JR, Littlejohns P, Karnon J, Merlin TL, Hiller JE: Identifying existing health care services that do not provide value for money. Med $J$ Aust 2009, 90(5):269-73.

3. Mitton C, Donaldson C: The Priority Setting Toolkit: A Guide to the Use of Economics in health Care Decision Making. London: BMJ Books; 2004

4. Peacock S, Ruta D, Mitton C, Donaldson C, Bate A, Murtagh M: Using economics for pragmatic and ethical priority setting: two checklists for doctors and managers. BMJ 2006, 332:482-85.

5. Mitton C, Donaldson C: Twenty-five years of program budgeting and marginal analysis in the health sector, 1974-99. J Health Serv Res Policy 2001, 6(4):239-48.

6. Haas M, Viney R, Kristensen E, Pain C, Foulds K: Using programme budgeting and marginal analysis to assist population based strategic planning for coronary heart disease. Health Policy 2001, 55(3):173-86.

7. Gibson JL, Mitton C, Martin DK, Donaldson C, Singer PA, Ethics \& economics: Does program budgeting and marginal analysis contribute to fair priority setting? J Health Ser Res Policy 2006, 11(1):32-7.

8. Donaldson C, Bate A, Mitton C, Dionne F, Ruta D: Rational Disinvestment. QJM 2010, 103(10):801-807.
9. Jan S: A perspective on the analysis of credible commitment and myopia in health sector decision making. Health Policy 2003, 63(3):269-78.

10. Baltussen R, Youngkong S, Paolucci F, Niessen L: Multi-criteria decision analysis to prioritize health interventions: Capitalizing on first experiences. Health Policy 2010, 96(3):262-4

Pre-publication history

The pre-publication history for this paper can be accessed here: http://www.biomedcentral.com/1472-6963/11/169/prepub

doi:10.1186/1472-6963-11-169

Cite this article as: Mitton et al: Difficult decisions in times of constraint: Criteria based Resource Allocation in the Vancouver Coastal Health Authority. BMC Health Services Research 2011 11:169.

\section{Submit your next manuscript to BioMed Central and take full advantage of:}

- Convenient online submission

- Thorough peer review

- No space constraints or color figure charges

- Immediate publication on acceptance

- Inclusion in PubMed, CAS, Scopus and Google Scholar

- Research which is freely available for redistribution 